\title{
THE EFFECT OF ONLINE LEARNING ON STUDENTS' WRITING CREATIVITY IN WRITING DESCRIPTIVE TEXT ABOUT LOCAL TOURISM
}

\author{
Irma Khoirot Daulay, Ekrina Lidwina br Ginting, Febri Oktavia \\ Manik, Wulan Siringo-ringo, Hotlina Sitohang \\ Universitas Prima Indonesia, Medan, Indonesia \\ E-mail: irmaemhum@gmail.com
}

Received: 2021-10-25

Accepted: 2021-11-20

\begin{abstract}
As a result of the pandemic, the best alternative to support formal learning activities is online learning, and it is believed to affect students' creativity in writing. The research aims to discover the effect of online learning on students' creativity in writing descriptive texts about local tourism. The methodology used by researchers in this research is a true-experimental method with a quantitative approach. This study uses a type of post-test-only control class design. There are two clases in this experiment design, each selected randomly. After conducting the study, researchers found a significant difference in grades between classes that received online learning treatment (experimental classes) and classes that were not (Control classes), where the experimental class scores were higher than the control class. So, the conclusion is that online learning has a good Effect on students' creativity in writing descriptive texts about local tourism.
\end{abstract}

Keywords: Online Learning, Writing, Creativity, Descriptive Text, Local Tourism

\section{Introduction}

Research about the effect of online learning on students' writing creativity in writing descriptive texts about local tourism is motivated by the pandemic of Covid-19 that provided many changes to the order of many people's lives. Education is one part of people's lives that are changing. To prevent the spread of the virus, the Indonesian government is implementing online learning affecting face-to-face learning usually held in schools. Different learning methods have their respective advantages and disadvantages, affecting students' understanding of the learning material. Online learning has its difficulties for both teachers and students. Based on a survey of 20 high school students, it is known that students experience some difficulties with online learning in the implementation. It can be concluded that the leading causes of these difficulties are the lack of supervision, unstable internet networks, and the expensive internet quota.

As one of the learning subjects taught at school, English has four bases in learning; one of them is writing. Writing is an indirect way of communicating that requires skills to express ideas, thoughts, knowledge, and experiences in written form (Aidid, 2020). Writing has many benefits, such as: improving memory, enriching insights, giving readers an impression, and adding vocabulary (Usman, 2019: 7-9), but 
writing also has its difficulties. Writing skills are more challenging to master than other language skills, even by speakers of the relevant language this is because writing is not just how students express their ideas in writing, but students also have to pay attention to the aspects of writing. Therefore, the role of the teacher is considered very important to direct students in writing learning. One of the writing skills that need to be improved is descriptive text writing skills. Descriptive text is a text that aims to describe an object specifically. Besides having to master the generic structure and language future of the descriptive text, to write descriptive texts, creativity is also needed so that students can make novelties both in terms of ideas and uniqueness of the way they are conveyed. Using a local tourism theme is an excellent idea to write a descriptive text because by writing descriptive text with the theme of local tourism that students have visited, they are expected to describe the object specifically. After all, the writing is based on their own experience and not just the image they see so that it can make readers feel the tourism object depicted, even though they did not see it directly and also The reason why researchers use local tourism as a theme is that researchers hope this will treat students' longing for travel activities - considering that for more than one year, there have been restrictions on mobility as a result of the pandemic, which then resulted in tourism activities experiencing a drastic decline - to generate student creativity. Meanwhile, local tourism is a place in a particular area known for its natural beauty or historical stories owned by the place so that it attracts the interest of others to visit it (IK Daulay, 2021).

Many things can influence students' creativity in writing, especially writing about the description of a place, such as local tourism. In this study, the researcher defined the problem, where the problem to be raised was only whether online learning affected students' writing creativity about local tourism or not. If online learning does affect students' writing creativity, it will be presented in percentages.

This research is expected to contribute knowledge to teachers, students, and the general public. For teachers, this study is expected to assist teachers in considering/deciding appropriate learning methods and media in teaching writing descriptive texts. For students, they are expected to be able to use existing learning media to support them. This research is expected to provide information that can be used in doing related research for another researcher. For the general public, this research is expected to be able to provide new knowledge for readers.

\section{Literature Review}

Online learning or E-learning is defined as an abroad generic term that describes various electronic technologies to convey learning. Such technology can be the form of computers, the internet, or various electronic equipment such as audio/radio and video/television (Parawiradilaga et al., 2019). In research conducted by Ali Sadikin and Afreni Hamidah (2020) at Jambi University, Students found that students are more comfortable conveying ideas on online learning. The psychological pressure experienced by students from peers is also reduced and can increase the independence of learning.

Learning about linguistics is never separated from the four basic abilities that must be mastered, and one of them is writing. Writing is part of the language field that requires creativity and good knowledge; this is because, in writing, many elements must be applied at once (Daulay, I.K. \& Asrul). As one of the English skills, writing is critical because, with writing, students can communicate and express ideas and feelings 
(Firdaus, 2020). Writing skills are pretty challenging to master. To gain the ability to write is not enough to master grammar and learn the writing theory, but must be accompanied by practice and guidance. Writing means creating or expressing feelings and thoughts through a symbol that has been agreed upon by one language user and the other (Sidik, 2016:3-4).

The descriptive text focuses not only on visualizing an object but also on how the author transfers impressions, transfers his observations and feelings to the reader, and conveys the nature and details of the form that can find on the object (Sidik, 2018:18). In writing a description, careful observation and accuracy are needed to describe an object. For that, the writer must understand the characteristics of descriptive writing.

The characteristics of the description, according to M. Atar Semi (2007: 66) there are five, namely:

1. The descriptive essay shows details or details about the object.

2. Descriptive essays are more emotional and affective shape the imagination of the reader.

3. Descriptive essays generally involve objects that can view

4. Senses by the senses so that the thing is generally in the form of Objects, nature, colors, and people.

5. Submission of descriptive essays in an attractive style and with evocative choice of words.

6. The organization of presentation is more generally uses the arrangement of space.

Several journals raise Munandar's opinion about crucial aspects that must be considered in describing creativity, such as Nurul Dwi Lestari's article (2018) and Lulu Anggi Rosalia., et al., (2016). According to Munandar, there are five aspects of creativity assessment, namely fluency, flexibility, originality, and evaluation

Indonesia is one of the countries rich in natural beauty, and this is also why there is so much local tourism spread almost all over Indonesia. In addition to honing the ability and creativity of students when writing descriptive texts, writing things related to local tourism can also spur students to create descriptive texts that are not only interesting but can also expand the knowledge of tourists who want to be interested in visiting local tourism in North Sumatra (Daulay, I.K., 2021).

\section{Research Method}

The methodology used by researchers in this research is a true-experimental method with a quantitative approach. This study uses a type of post-test-only control class design. There are two classs in this experiment design, each selected randomly. The first class was treated, and the other class was not. The class that was given the treatment was called the experimental class, and the class that was not given treatment was called the control class. (Rugminingsih et al., 2020)

The population used in this study is X-grade students at SMA NEGERI 1 TIGABINANGA which consists of 9 classes with 314 students. After determining the population, the researchers selected the sample using the accidental sampling (nonprobability sampling) technique. The sample selected was class X MIPA 1, which acted as a sample for experimental conditions, and X MIPA 2 became a sample for control conditions. 
The Effect of Online Learning on Students' Writing Creativity in Writing Descriptive Text about Local Tourism, Irma Khoirot Daulay, Ekrina Lidwina Br Ginting, Febri Oktavia

Researchers have conducted a series of processes to obtain the required data, including tests for both classs and treatments for the experimental condition class. The test was conducted by asking students from each class (control and experimental conditions) to write descriptive text-themed local tourism within 80 minutes. Unlike the control condition class, the experimental condition class has passed the process of providing manipulation (treatment) in online learning through Google Classroom first before doing the test. The test has been carried out in the hall of SMA NEGERI 1 Tigabinanga by complying with health protocols such as wearing masks, washing hands, and practicing physical distancing.

The collected data in student worksheets are then assessed using five aspects of assessment proposed by Utami Munandar (Lestari, 2018), namely fluency, flexibility, originality, elaboration, and evaluation. Each aspect will be measured from numbers 1 to 5 .

What will be measured on the fluency aspect is the number of words students can write within 80 minutes; if the student can write 200 words or more, then the student will get a score of 5, if able to write 150-199 words, then the score obtained is 4 . If able to write 100-149 words, then the score will be 3 . If the number of words obtained is 50-99, then the score is two, and if only able to write $0-50$ words, then the score is 1 .

On the aspect of flexibility, which will be assessed is the diversity of sentence structure, which can be in the form of a combination of sentences (1) simple, combined, and complex, or (2) long sentences (short sentences of less than five words, long sentences of more than ten words). Suppose there is flexibility in content or ideas that include the use of (3) specific adjectives, (4) organizational patterns, (5) author impressions. Students will get one score each time they meet 1 Criteria.

Originality is measured from 5 criteria, including (1) novelty of ideas, (2) valuable/functional, (3) uniqueness of objects, (4) surprises, (5) relevant. (Very original, get five scores). Students will get one score each time they meet 1 Criteria.

The criteria used to measure elaboration are if students were able to detail objects described, including aspects of the place (position, direction), size (weight, volume, distance), shape/pattern, color, texture, name of material/tool, function, value, and other technical vocabularies. Same as the previous aspect, elaboration will also be measured from numbers 1 to 5 .

The evaluation section of the assessment criteria to be given include the student's ability to provide an objective assessment through sensory impressions (sight, hearing, smell, taste, touch, and feeling). This aspect will also be measured from numbers 1 to 5 .

Creativity also ranges from very creative, creative, quiet creative, less creative, and not creative. Here is presented the rubric aspects assessed in the creativity assessment:

\begin{tabular}{lllllll}
\hline No & Aspects & \multicolumn{5}{c}{ Score } \\
& Assessed & $\mathbf{1}$ & $\mathbf{2}$ & $\mathbf{3}$ & $\mathbf{4}$ & $\mathbf{5}$ \\
\hline 1 & Fluency & & & & \\
\hline 2 & Flexibility & & & & \\
\hline 3 & Originality & & & & \\
\hline 4 & Elaboration & & & & \\
\hline 5 & Evaluation & & & & \\
\hline
\end{tabular}


The level of creativity is determined by summing the score obtained by students based on the aspects described in table 2.1, where students are said to be creative if the number of scores obtained between 21-25, said to be creative if the score is between 1619 , is said to be quite creative if the score is between 11-15, it is said to be less creative if the score is between 6-10, and it is said to be not creative if the score is between 1-5.

After getting the research data, the next step that the researcher has done is to conduct a t-test on the two research subjects with a significance level of $5 \%$ by using IBM SPSS Statistic 25 to get the results in the form of mean, degree freedom, standard deviation, significance ( $\mathrm{p}$ value), $\mathrm{t}_{\text {observed }}, \mathrm{t}_{\text {table. }}$.

\section{Discussion}

Same as generally quantitative data, this study also uses statistics as a data analysis technique. The type of statistics used is inferential statistics (probability statistics) in which the conclusions that are applied to the population based on the truth sample data are probability. (Sugiyono, 2013:148).

The data that has been collected before, then entered into the SPSS table and analysis them by compare the means through t-test of two independent samples where the hypotheses used are:

$\mathrm{HO}$ : There was no difference in scores between the control class and the experimental class.

H1 : There was a difference in scores between the control class and the experimental class.

$\mathrm{H} 0$ is allowed if $t_{\text {observed }}>t_{\text {table }}$

The finding of the data that has been collected are presented in the form of Chart as below:

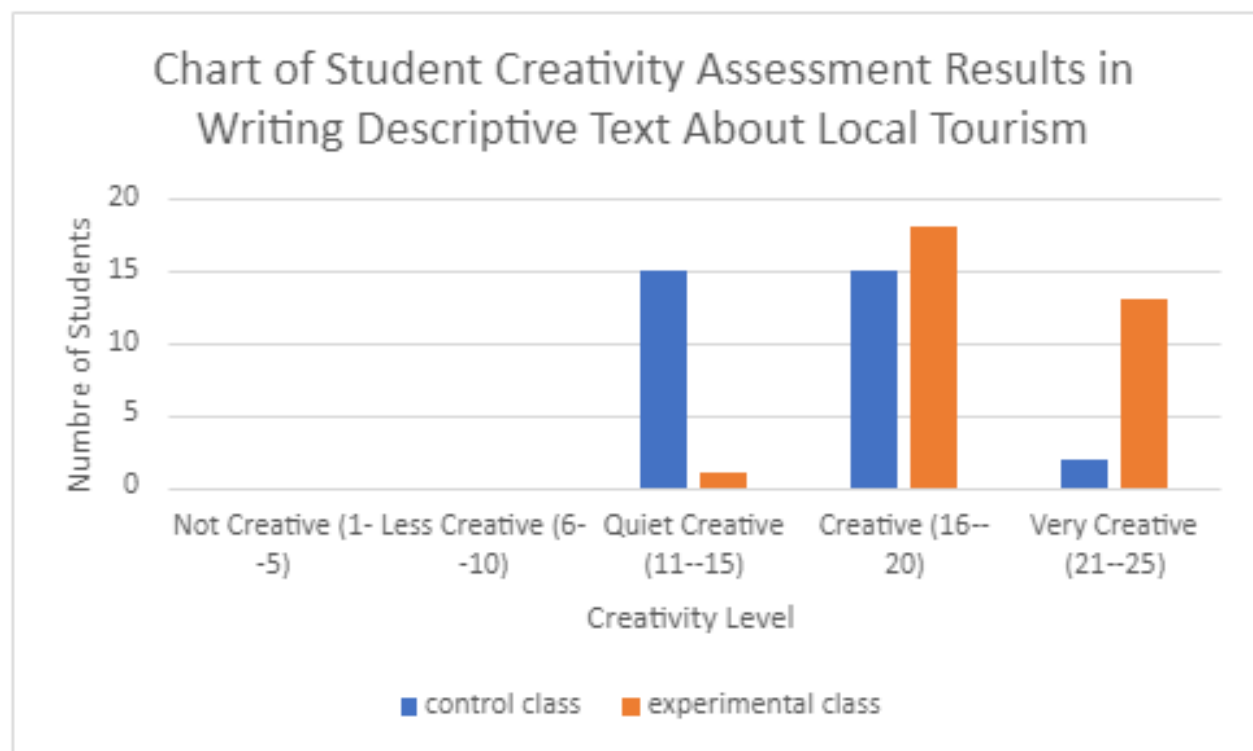

Following what has been explained before, that this study conducted statistical data analysis with SPSS. Results from statistical data show that the average score of the control class is 16.03 , with a standard deviation of $3.1(\mathrm{M}=16.03, \mathrm{SD}=3.1)$ while the 
The Effect of Online Learning on Students' Writing Creativity in Writing Descriptive Text about Local Tourism, Irma Khoirot Daulay, Ekrina Lidwina Br Ginting, Febri Oktavia

experimental class has an average of 19.19 with 2.7 standard deviation $(\mathrm{M}=19.19$, SD $=2.7)$.

To compare the average of two sample conducted independent t-test sample and showed result as below:

\begin{tabular}{|c|c|c|c|c|}
\hline \multicolumn{5}{|c|}{ Independent Samples Test } \\
\hline & & & \multicolumn{2}{|c|}{ Score } \\
\hline & & & $\begin{array}{c}\text { Equal } \\
\text { variances } \\
\text { assumed }\end{array}$ & $\begin{array}{c}\text { Equal } \\
\text { variances not } \\
\text { assumed }\end{array}$ \\
\hline \multirow{2}{*}{$\begin{array}{l}\text { Levene's Test for Equality } \\
\text { of Variances }\end{array}$} & $\mathrm{F}$ & &, 787 & \\
\hline & Sig. & &, 378 & \\
\hline \multirow{7}{*}{$\begin{array}{l}\text { t-test for Equality of } \\
\text { Means }\end{array}$} & $\mathrm{t}$ & & $-4,385$ & $-4,385$ \\
\hline & df & & 62 & 61,050 \\
\hline & Sig. (2-tailed) & &, 000 &, 000 \\
\hline & Mean Difference & & $-3,156$ & $-3,156$ \\
\hline & Std. Error Difference & &, 720 &, 720 \\
\hline & \multirow{2}{*}{$\begin{array}{l}95 \% \text { Confidence Interval } \\
\text { of the Difference }\end{array}$} & Lower & $-4,595$ & $-4,595$ \\
\hline & & Upper & $-1,718$ & $-1,717$ \\
\hline
\end{tabular}

Based on the table presented above, the homogeneity test can first be carried out with the F test (Levene's test), where the hypotheses used are as follows:

H0: The control class variant is the same as the experimental class.

H1: The control class variant is different from the experimental class.

The $\mathrm{H} 0$ testing criteria are accepted only if the p-value $>0.05$ and vice versa. In Tabel, it can be known that the value of $\mathrm{p}$ is 3.78 , and the significance value is 0.05 , so $\mathrm{H} 0$ is accepted. Because the F test shows that both variants are the same, the score used is 'equal variances assumed.' As written in Table above, the value of $t$ is 4,385. The degree of freedom (df) is 62 ; with the discovery of the value $\mathrm{df}$, the value of the t-table is 1.67. At the same time, it is also known the value $p<0.001$ with the $\alpha=5 \%(0.05)$ thus can be written the following equation:

$$
\begin{aligned}
& \mathbf{t}_{\text {observed }}>\mathbf{t}_{\text {table }}(\text { with df } 62) \\
& 4.385>1.67 \text { (with df } 62)
\end{aligned}
$$

and

$\mathrm{P}$ value $<\alpha$

By the statement on the hypothesis of the test $t$ that has been submitted $\mathrm{H} 0$ was rejected because the value of $t_{\text {observed }}$ is higher than the $t_{\text {table }}$ and the $p$-value is smaller than $\alpha$, or in other words, there is a significant difference between the average grade $\mathrm{X}$ MIPA 1 (experimental class) with class X MIPA 2 (control class) where the average value of class X MIPA 1 is higher than X MIPA 2, This can be seen from the observed score which shows a negative value. With the rejection of $\mathrm{H} 0, \mathrm{H} 1$ is automatically accepted. 


\section{Conclusion}

Online learning has an effect on students' creativity in writing descriptive texts about local tourism. This can be proven by the conduct of a series of processes that aim to compare the average value of student test results in writing descriptive text so that results are obtained that show a significant difference in average scores between control class and experimental class where the average comparison between the two classes shows that the average value of experimental classes (which get treatment in the form of online learning) is higher than control classes that do not get treatment so it can be concluded that online learning has a positive effect on students' creativity in writing descriptive texts about local tourism.

\section{References}

Daulay, I. K. \& Asrul, N. (2021). The effect of media guessing game towards university students' writing ability on descriptive text local tourism content. English Review: Journal of English Education, 9(2), pp. 163-172.

Daulay, I. K., \& Hasugian, K. B. (2021). The Effect of Using Guessing Game Media Themed Local Tourism on Students' Achievement in Writing Narrative Text. Budapest International Research and Critics Institute (BIRCI-Journal): Humanities and Social Sciences, 4(1), 1178-1185

Firdaus. (2020). Learning Describtive Writing With Local Tourism Destination Picture. Jawshiyah. Volume 15, Nomor 1, Hal. 1-27.

Lestari, Nurul Dwi. (2018). Pembelajaran Autentik dalam Menulis Teks Deskripsi. EFECTOR. Volume 5, Hal. 74-85.

Prawiradilaga, Dewi Salma. (2013). Mozaik Teknologi Pendidikan. Jakarta: Prenadamedia Class.

Rhosalia, Lulu Angai. Laksono Kisyani., dan Sukarningsih Wahyu. (2016). Kemampuan Menulis Kreatif dalam Menulis Naratif Kelas V Sekolah Dasar Negeri di Kecamatan Gayungan Surabaya. Jurnal Riview Pendidikan Dasar Jurnal Kajian Pendidikan dan Hasil Penelitian. Volume 2, No. 2, Hal. 166-174.

Rugmaningsih., et al. (2020). Metode Penelitian Pendidikan. Yogyakarta: Erhaka Utama.

Sadikin, Ali dan Afreni Hamidah. (2020). Pembelajaran Daring di Tengah Wabah Covid-19. BIODIK: Jurnal Ilmiah Pendidikan Biologi. Volume 6, Nomor 02, Tahun 2020, Halaman. 214-224.

Semi, M. Atar. (2007). Dasar-Dasar Keterampilan Menulis. Bandung: Angkasa.

Sidik, Mohammat. (2016). Dasar-Dasar Menulis Dengan Penerapannya. Malang: Tunggal Mandiri Publishing.

Sidik, Mohammat. (2016). Penerapan Menulis Deskripsi Untuk Pendidikan Dasar. Malang: Tunggal Mandiri Publishing.

Sidik, Mohammat. (2018). Pengembangan Model Pembelajarn Menulis Deskripsi. Malang: Tunggal Mandiri Publishing.

Sugiyono. (2013). Metode Penelitian Kuantitatif Kualitatif dan R\&D. Bandung: Alfabeta.

Usman, Mariya. (2019). Mengapa Menulis Itu Penting. Denpasar:Guepedia. 